\title{
TAMING THE DRAGON: MALAYSIA-CHINA RELATIONS AND ITS IMPACT ON EAST ASIAN REGIONALISM
}

\author{
K. S. Balakrishnan
}

\begin{abstract}
This article adopts a position that Malaysia's relations with China in recent decades have not only facilitated in the upgrading of bilateral relations, but also made a significant impact on the overall intraregional relations in East Asia. Malaysia was the first Southeast Asian country to improve ties and establish official relations with China in 1974. With the end of the Cold War, the relationship between Malaysia and China flourished, mainly towards enhancing trade, investment and other bilateral areas. Malaysia's footstep was followed by other ASEAN members. The overall ASEAN-China relations improved further in the age of intense regionalism and globalization. This led to the establishment of the ASEAN-China FTA (Free Trade Agreement) and ASEAN Plus Three. Malaysia's active and positive pursuit in strengthening ties with China has had a significant impact on ChinaASEAN relations. Almost all ASEAN members are looking at the regional platform to engage China. Larger platforms like the EAS and $R C E P$ are cementing further not only intra-regional relations involving China, but also the bilateral ties. Although there are occasional hiccups in relations due to security issues, Malaysia's leadership in regionalism and capitalizing on China's economic rise had been the main driver in the overall East Asian regionalism. China too is fully aware and appreciates the special ties with Malaysia and ASEAN.
\end{abstract}

Keywords: Regionalism, bilateral relations, Malaysia-China relations, ASEAN-China Relations, ASEAN Plus Three, free trade agreement

\section{INTRODUCTION}

International relations in Asia, particularly in the East Asian region, are definitely experiencing a remarkable shift with the end of the Cold War and the post-Uruguay Round of the GATT. States that were enemies 
at one time have become friends propelled by high economic growth and the expansion in international trade. The rise of regionalism has further opened-up their boundaries. However, the excitement over regionalism and the regional process needs to be examined carefully. This article is an attempt to analyse East Asian regionalism involving namely two major players, ASEAN and China. It will trace how the trend in bilateral relations between two countries, namely Malaysia and China, shapes ASEAN-China or East Asian regionalism. Whether East Asian regionalism is one that emanates from the real internal dynamics of the region or is one that is driven by bilateral initiatives within a region is indeed an important question and demands further scrutiny. It will expose how trends in Malaysia-China bilateral relations impact upon regionalism in East Asia. Finally, this essay will provide a critical perspective by relating to the numerous issues surrounding the so called East Asian regionalism. While on the one hand, bilateralism has had a positive impact on the East Asian regionalism involving China and others, on the other, the ASEAN countries need an overarching perspective in understanding on what constitutes regionalism and how it should be pursued.

\section{REGIONALISM: A THEORETICAL AND CONCEPTUAL EXPLAINATION}

Regionalism is a contested concept. Its meanings are often ambiguous in the present context, particularly so in the age of contemporary globalization. In the past, regionalism was initiated or concluded based on a particular national and alliance interest, identity or sense of cooperation for common security among nations or even kingdoms for that matter. Regionalism was often known as a process with common goals and shared identity based on a common geographical area or proximity. This is further beefed by a common cultural patterns or heritage of the people including some similarity in the sense of language and ethnic identities. The above scenarios and similarities no longer apply in a fixed manner as we analyse regionalism in the age of contemporary globalization. Today, regionalism has moved from the old geographical and security constructs of the Cold War structures involving geo-strategic regions to one that of expansive in nature. In fact, the ascent of the recent economic globalization after Cold War and the post-GATT era has created a significant impact on 
regionalism. The way regional organizations evolve be it on security cooperation or via economic collaboration creates a new understanding on the theory and models of regionalism.

There seems to be a major shift underway from what was known as 'old regionalism' earlier, into one that is known as 'new regionalism'. Today, regionalism is also discussed in the context of open regionalism and multiple regionalisms. From a theoretical perspective and approach, the setting up of regional organizations and processes must be viewed at first from a functionalist perspective, involving the creation of international entities or organizations to serve particular form of cooperation. In line with this, one could relates to the theories of liberalism, neo-realism, constructivism and so on to categorize regionalism and its initiatives which can be regarded as regional in orientation, where states establish the habit and structures for cooperation. Arndt (1993) acknowledged that regionalism is getting popular and it means almost all things to people of all walks of life. But he divided the kind of regionalism into several categories. These include the regionalism of the contemporary era based on 'preferential trading arrangements' that were inward looking like that of the European Community or the US-Canada Free Trade Area that was gaining momentum then. He also pointed out to the initiatives of sub-regionalism and open regionalism and sub-national regionalism. ${ }^{1}$ Regionalism in Asia too followed a similar pattern like in the West.

While sub-national regionalism is basically about internal developments and areas within a country, the other three types such as the preferential trading arrangements (PTA) or in current context the FTAs, sub-regionalism (such as growth areas) and open regionalism are international in nature, explaining the changing dynamic of regionalism with the failure of the GATT regime in the late 80s. Today, the constructivist perspectives have even taken regionalism to another level of thinking based on identity. While we have a model of supra-national entity in the form of the European Union (EU) style of regionalism, the mushrooming of functionalist regional organizations that claims to be a regional community too are flourishing, as in the case of ASEAN, the East Asia Summit (EAS) process, ASEAN Regional Forum (ARF) and the Asia Pacific Economic Cooperation (APEC). Overall, the above models led to the encouragement on regional 
political, security, and economic initiatives toward liberalizations. They claim to be comprehensive in nature rather than being parochial.

Open regionalism too has gained momentum as a conceptual model in the 1990 s to further encourage economic regionalism in order to attain the goals of globalization and counter the emergence of close or exclusive powerful trading block which can lead to economic rivalry. Organizations like the Pacific Economic Cooperation Council (PECC) and the Asia Pacific Economic Cooperation (APEC) were leading examples and became the proponents of 'open regionalism' that was non-discriminatory in nature. ASEAN (Association of the Southeast Asian Nations) and SAARC (South Asian Association for Regional Cooperation) too started moving in the direction of open regionalism since the establishment of AFTA and SAFTA. ASEAN adopted open regionalism by promoting the AFTA (ASEAN Free Trade Area) mechanism for tariff reductions and trade promotion and this was later followed by SAARC (South Asian Association for Regional Cooperation) by announcing its SAFTA (South Asia Free Trade Area) mechanism for the liberalization of economies within their respective region.

Recent years have witnessed numerous Free Trade Areas and Free Trade Agreements being signed at both regional and bilateral levels, altering the very nature of what can be regarded as region or regional initiatives or the regionalization process. European and African regionalism can be explained as one that shares common features of a region within a geographic continent. But the era, context and mechanism are different. Regions of the developing world are all accelerating the regionalization process by looking EU and others. However both the EU and regions of the developing world are having their own problems and pitfalls in managing the onslaught of globalization in an era of digital economy. Nevertheless, this will not stop regionalism from flourishing.

\section{TRENDS IN MALAYSIA-CHINA BILATERAL RELATIONS: HISTORY AND THE ROLE OF LEADERSHIP IN STRENGTHENING TIES}

While it can be argued that the historical linkages of Malay-Sino bilateral relations can be traced back to the Han and Ming Dynasty, 
it is important to take into account that relationship in the era of kingdoms cannot be equated with that of the modern post-colonial era. Malaya gained independence in 1957 from Britain. China too had experienced British presence of some sort and Hong Kong was returned to the Chinese fold only in 1997 . While there exists several writings on the tributary systems of the Malay sultanates, it must be attributed that such relationship was marred by the presence of Admiral Zheng He's (Cheng Ho) naval expedition to Malacca. Although it was regarded as benign, the sheer size of the expedition could strike fear of the small Malay kingdoms of only a few thousand people. The nature of traditional international relations itself reveals the problem of size, significance and impact. Malacca was for China an important landmark in curbing the rise of India influenced kingdoms. What more when such kingdoms were an established feature of not just Malaya, but the whole of Southeast Asia including in Indochina. What surprises us even today is that the contemporary analysis of international relations in Southeast Asia once more reveals similar trend. Both India and China are rivals for influence in Southeast Asia in the modern and post-modern era. The presence of the West, be it American or the European influence is only another impediment, both in military and economic sense.

Malaysia-China bilateral relations and Sino-ASEAN relations in the post-War era were affected by two important features. First, is the communist uprising in the People's Republic of China which supported the spread of communism as an anti-colonial element in order to free Southeast Asia and absorb it under the communist lake via support for the communist parties that promoted such armed struggle against the locals and colonial interest. Malaya was facing the challenge of communist activism to a level that Britain started the declaration of the Emergency in 1948, which lasted until 1960. Although the Communist Party of Malaya (CPM) was successfully defeated, it only became officially defunct in 1989 with an agreement signed in Hatyai, Thailand. For many years, Chin Peng and some cadres were residing in Southern Thailand. Sporadic communist attacks were quite popular in the 1970 s and 1980 s.

China was never positive of the Malayan independence in 1957. Beijing also did not support the formation of Malaysia in 1963 due to Kuala Lumpur's allegiance with the Western countries. Tunku foreign 
policy too was one that of openly pro-West and anti-Communist in nature in the first decade of independence. This had delayed diplomatic relations. Malaysia became the first ASEAN nation to establish diplomatic relations with the PRC in 1974 after the famous Tun Abdul Razak's visit to Peking on 28 May, 1974. Malaysia also supported China's accession into the UN Security Council in 1971. Tan Sri Michael Chen was instrumental in the early 1970s in passing the friendship message to the Chinese counterpart a letter from Tun Abdul Razak when he was asked by Razak to lead a ping pong team to the Afro-Asian-Latin America Table Tennis Championship held in Peking. In his view, this was the initial part of what he called as China's 'Ping Pong Diplomacy' using sports as the forefront. ${ }^{2}$ Razak also encouraged trade delegations to China prior to his visit in 1974. Razak's visit in May 1974 was the most successful historical event in Malaysia's foreign policy although bilateral relations did not flourish immediately after that visit. It shifted Malaysia's foreign policy priority in support of the developing world and also in line with the 1971 ZOPFAN (Zone of Peace, Freedom and Neutrality) concept which advocates neutrality as key principle. This was not the same with Tunku Abdul Rahman as prime minister. He was more known as pro-West and anti-communist. Razak had his difficulties but was able to make bold decisions after the racial riots in 1969. Although some would have seen that as bowing to the Chinese, however it brought a positive impact when election was held in 1974 where the National Front (Barisan Nasional) was able to secure a formidable victory and form a democratic government once more after the state of emergency after 1969.

The second issue of problem area was the huge presence of the Chinese communities of which their citizenship and loyalty remained questionable in the eyes of the governments in power in Southeast Asia. Malaya, Indonesia and Singapore had to deal with this problem given the activism of the communist parties and the support of the local Chinese populations to these elements. The communist parties too looked up for inspiration and practical support to Moscow and Peking. In addition to this challenge, Malaysian leaders too were upset up till the mid-80s when China could issues separate travel documents to the local Chinese for visiting the PRC. This was regarded by the Malay government as sabotaging the national attempt towards integration 
and unity. China felt that was not wrong because of the discrimination faced by the overseas Chinese. ${ }^{3}$

However Razak's visit and the normalization of the relationship paved ways for two more ASEAN members to follow suit in establishing diplomatic relations. By 1975, Thailand and the Philippines had also established their diplomatic relations. Indonesia only resumed diplomatic relations in 1990 after suspending its bilateral relations in 1967. Singapore too built the relationship with Beijing in 1990 and this was followed by Brunei in $1991 .{ }^{4}$ Rivalry for influence in the Southeast Asian affairs had also made China's relations with the Indochina states on the wary path for some decades. The situation in Indochina too was not all that rosy as the region has to deal with Vietnam and its influence in Cambodia. China's support for the Pol Pot regime and the Khmer Rouge was not something historically praise worthy. Malaysia was not in favour of China's activism in Indochina. In fact, China-Vietnam rivalry in trying to be the hegemonic powers in Indochina had an effect on ASEAN's policy towards Indochina and China during the 80 s and 90 s.

The scenarios changed with the end of the Cold War, with the withdrawal of USSR assistance to Vietnam and Russia's withdrawal from the bases in Danang and Cam Ranh Bay. The decline of the Russian support had weakened Vietnam's position. China too became accommodative of ASEAN's plan while always wanting to ensure that the Khmer Rouge had their interest and representation sufficiently guarded under the coalition government planned by ASEAN and the US. ${ }^{5}$ For Malaysia, the issue of peaceful settlement of the Cambodian conflict and crises in Indochina was of significant importance in its foreign policy calculations between the late 1970s and mid-1990s. This was simply due to the fact that Malaysia faced serious influx of refugees or the 'boat people' coming from Indochina. The cooperation of Vietnam was important as much as the settlement of the Cambodian conflict. Keeping Indochina as the battleground for superpower rivalry was not of interest for Malaysia. The concern over China's foreign policy and its behaviour in the peaceful settlement of the Indochinese conflict became crucial in influencing both Malaysia and ASEAN's view of Beijing's sincerity. However, it did not create a scenario for Malaysia for harming diplomatic ties with China. But the above three issues delayed Malaysia's pursuit of warming up towards China. 
Further, in 1979, Deng Xiaopeng visited Kuala Lumpur. Although this was later reciprocated by Hussien Onn by visiting China, it did not enhance bilateral relations in a significant manner. ${ }^{6}$

Malaysia-China relations were hanging on a thin thread due to the reasons of security and political in nature. In fact, Mahathir postponed his visit to Beijing in the mid-80s despite the invitation from China. Although he later cemented the relationship by 1988, there was no sufficient impetus to move forward the bilateral relations. Perhaps the end of the Cold War with the collapse of the USSR became an important factor to pursue stronger ties with the communist world. This was also beefed up by an economically rising China. By early 90s, Mahathir became the first in ASEAN to openly state that the communist world was no longer a threat. By the mid-90s, Mahathir was often quoted as a leader who saw China as opportunity rather than threat. Numerous speeches of Mahathir can be traced on the changing priority in Malaysia's foreign policy since the early 1990s. In fact Mahathir went on saying that Malaysia was not only the first in ASEAN to establish diplomatic relations but also the first in ASEAN to dismiss China as a threat. ${ }^{7}$ It is important to understand that government related think tanks like ISIS (Institute of Strategic and International Studies) Malaysia, MSRC (Malaysia Strategic Resource Centre), ASLI (Asian Leadership Institute) and MIMA (Maritime Institute of Malaysia) also played important role throughout the 1990s and until the leader's retirement in changing attitudes of the Mahathir regime, because of their wide range of activities which embraced China and East Asia in a positive manner.

Mahathir saw the rise of China in a completely new light mainly from a business and international political economy perspective although trade was still marginal at that time. By December, 1990, Mahathir used the visit of the Chinese Premier Li Peng to announce the intention of establishing the East Asian Economic Grouping (EAEG). The issue of pursuing further the EAEG became more apparent once Mahathir realized he had China's backing. It was an important opportunity for Malaysia to stir its foreign policy direction which was in line with the 'Look East' policy which Mahathir had been cultivating since the early 80 s by looking at the progress made by Japan and South Korea. So the economic rise of China and its importance on shaping regionalism was in fact recognized first by 
Mahathir as a counter-weight against the West. China too had been all the way consistent in providing support EAEG/EAEC policy initiative compared with say South Korea or Japan.

Mahathir officially visited China at least six times during his tenure as Prime Minister, namely in 1985, 1993, 1994, 1996, 1999 and 2001. Mahathir also visited China for attending the Bao Forum and APEC Summit. ${ }^{8}$ He also visited China to commemorate the 1974 visit in 1994. He missed the opportunity in 1984 as he was still looking up to Japan than China at that time in championing his Look East foreign policy. China too was not economically that attractive in 1984. President Jiang Zemin too visited Kuala Lumpur in 1994. His deputy Hu Jintao visited Kuala Lumpur in April 2002. Premier Li Peng and Zhu Rongji had all made their visits during the Mahathir era. Malaysia's King (Yang Dipertuan Agong) too officially visited the PRC denoting the importance placed by the Mahathir administration in constructing strong relationship with China. Since the early 1990s, Mahathir brought huge business delegations during his visits to China. The idea was to explore the opportunity which China presented in enhancing Malaysia's trade. It was also politically correct as such visits draw huge media attention among the local Chinese. This was important for Mahathir to strengthen his image among the local ethnic Chinese as he was historically known as belong to the 'ultra' nationalist camp who champions the Malay right at all expense. The Malaysia-China Friendship Association and China-Malaysia Friendship association were all established in the early 90s. Besides these associations, agreements and cooperation in the field of media, education and bilateral trade and economic relation were all concluded between the early and mid-90s by the Mahathir administration. Malaysia had also supported China's entry in the WTO in 2002.

Overall, Mahathir's China adventure was highly useful in increasing economic relations not only at the bilateral level but as well for regionalism. In fact, one could easily argue that no ASEAN leaders could have promoted the PRC the way Mahathir promoted China. His rhetoric of looking at China as 'opportunity' was well bought over by all the ASEAN leaders including his successors both Abdullah Badawi and Najib Tun Razak. By 1996, China became ASEAN's new Dialogue Partner of ASEAN. The status of this dialogue partnership, China's encouragement of Malaysia's EAEG and the phenomenal 
economic growth which it recorded in the modern history economic development had an important bearing on regionalism in East Asia. China was invited to the Chiangmai Initiative in 2000 in the plan for currency swap to ward off the recurrence of currency attack or the Asian economic crisis.

When Abdullah became prime minister in October 2003, he ensured that the year 2004 was given importance for a trip to China to commemorate the 1974 Razak initiative. Like Razak, Abdullah too had great election success in 2004. President Hu Jintao visited Kuala Lumpur in that year as well. Abdullah was responsible for encouraging the setting up of the Institute of China Studies in Kuala Lumpur as an important symbol of strong ties. By 2005, he invited China into his EAS (East Asian Summit) mold replacing the EAEG platform. Badawi expanded his Asia vision of embracing both China and India in the foreign policy front. India too joined the EAS. Abdullah and others had also visited China when they were the deputy prime ministers. This included Anwar Ibrahim and Ghafar Baba when both were deputy prime ministers. Anwar too brought a huge entourage on his way to China in the late 1990s. All the deputy prime ministers during the Mahathir era were accorded a pleasant treatment in Beijing. In September 2002, Abdullah Badawi made an official visit to China while he was almost ready to become prime minister the following month in October, 2003, replacing Mahathir.

This policy was further pursued by Najib who also brought huge delegation to Beijing in 2009 after becoming the prime minister in that year for commemorating the 35th anniversary of the Razak's visit. President Hu Jintao too reciprocated Najib's visit in the same year in September 2009, honouring Malaysia in a significant way. Najib went on as far as to state that there is something special about MalaysiaChina friendship. Najib's son was later sent to the Beijing Foreign Studies University for attending language and cultural courses. China too has honoured Malaysia with a special visit with the change of guard in Beijing recently. President Xi Jinping visited Malaysia and a few ASEAN members in October 2013. During his visit, China stated the intention of revitalizing the historical 'maritime Silk Road'. ${ }^{9}$ China was able to promise huge fund for development of infrastructure in Southeast Asia and in other region. It has indicated that it is capable investing up to US $\$ 500$ billion abroad on infrastructure projects. The 
intention to bring Malaysia-China trade to a level US\$160 billion by 2017 was expressed between the two states. ${ }^{10}$

\section{IMPACT ON EAST ASIAN REGIONALISM AND THE CHINA CHALLENGE}

By observing the decades of bilateral relations, one could see how the trends and pattern of the Malaysia-China relationship helped ASEAN and East Asia as a whole to foster regional relations. Regionalism involving China and ASEAN could only flourish because of the role played by several Malaysian leaders who were historically passionate about the 1974 Razak's diplomatic initiative with China. There were many difficulties in bilateral relations until the end of the Cold War. Mahathir too was initially cautious and did not visit China until 1985.

However, he started seeing the opportunity only in the early 1990s parallel to China's image as a new NIE (newly industrialize economy). This was further boosted by the fact that Mahathir was more business savvy then the rest of the predecessors. His successors both Badawi and Najib had no choice, but emulated Mahathir in promoting national interest and regionalism in Asia. But to state that the increase in bilateral relations and the promotion of regionalism with China in the last few decades was an easy path may not be true. While the economic and political relations are often referred as solid and expanding may be true, it is not all that simple. Problems and suspicion are plenty. Trust is hard to come although the two needs each other all the way to enhance each other's profile in the region and at the global level.

The main impetus for working together in Asia was when both China and Malaysia had a common national interest as developing countries, in ensuring that the post-Uruguay Round did not result in extensive favouring the Western interest in East Asia particularly when comes to establishing regionalism. Both Malaysia and China were apprehensive of Australia and the US initiated APEC. Unlike Malaysia, the other ASEAN countries were well convinced by the regional initiative of Australia and the US looking at APEC quite positively. Even Japan and South Korea for that matter were ambivalent of the EAEG. The US, New Zealand and Australia was excluded for not being Asian or part of Asia. The initiation of ASEAN Plus Three 
(APT) gave the necessary process for keeping alive the flame of the EAEG. As China became a dialogue partner of ASEAN in 1996, it was much easier to keep Beijing into the ambit of regionalism. China had also been invited into the ASEM (Asia-Europe Meetings) by ASEAN under similar framework of the ASEAN Plus Three or from Malaysia's point of view under the unofficial EAEC framework. By 2005, China became a member of the East Asia Summit (EAS).

In February 2009, the APT once more played a positive role in contributing towards so called Asian Monetary Fund or US\$120 billion stimulus package in order to cope with the global economic downturn. China, Japan and South Korea were to fund 80 percent while the remaining 20 percent will be topped up by ASEAN. China also expressed its desire to fund infrastructure projects via soft loans and to improve further its investment in ASEAN. China pledge additional US $\$ 10$ billion for ASEAN-China Investment find and US \$15 billion credit for infrastructure spending. ${ }^{11}$ Overall, ASEAN has been also happy with China currency policy since the 1997 crises. While the role played by China is commendable, the issue of regional integration in East Asia is somewhat flawed. Despite numerous trade agreements including the ASEAN-China Free Trade Agreement (ACFTA), regionalism in East Asia involving ASEAN, China and others has not been a major success story. The discussion and implementation of all the FTAs promoting regionalism has been mainly on tariff reduction to promote trade. Most of it has been more voluntary. Tariff reduction is slow and problematic although long list of good have been agreed. The implementation of AFTA has been challenged by issues like automobile industry and food items, namely agricultural products. Therefore, ASEAN and China too are having limitation on fully implementing the concept CAFTA to its desire direction. Politically, Japan is initiating another FTA for the whole of Northeast Asia. China and Taiwan have also signed free trade agreements that help boost their bilateral trade and investment. While some could argue that these new arrangement will help regionalism in East Asia, how much it will benefit ASEAN or Malaysia remains to be seen. China has only began to have sizeable investment in ASEAN states in recent years and it looks like China's fund will be more channeled in many Afro-AsianLatin American countries. China faces a major challenge in dividing its development assistance fund into several regions of the world. The expectation outside China is also growing. 
While ideas of the East Asia Economic Community and East Asia Security Community have been mooted and discussed well in the EAS and APT meetings, can China and ASEAN really work closely to realize this dream remains questionable. ASEAN and China faces numerous challenges on issues such as human rights, democracy, media freedom, Myanmar, South China Sea, military build-up and the US role in the region. Relationship with Taiwan, Japan and South Korea too become tense occasionally intensified by Chinese media, the public and the Beijing's foreign ministry and the military. China's consistent issuing of warning on numerous issues has done more harm than good. Within Southeast Asia, relationship with Vietnam and the Philippines has been spoilt by the issue of Spratlys. Suspicions are high indeed. While Malaysia has been constantly positive about the opportunity in China, the issue of South China Sea affects its feeling when Beijing protest Kuala Lumpur's initiative make claims by using the maritime law. China's fishermen have been posing problems not only for Japan but also ASEAN. Indonesia had a share of the problem recently. China's increase in defence spending and military build-up is a long term concern for ASEAN. Like ASEAN, the US, Australia and Japan have all been watching closely these developments. In fact over the last decade, its defence budget has grown more than US\$50 billion. Some in the West estimate China's defence budget could be up to three times the officially published budget. Individual countries of ASEAN like Malaysia too have numerous issues of concern in dealing with China.

Both Malaysia and ASEAN has been losing to China in many areas not just on FDI. Although Malaysia-China trade has increased many fold reaching US $\$ 50$ billion rendering credit to ACFTA, but the same cannot be said when comes intra-regional investment. China's investments in Malaysia and ASEAN still suffer in this regard. So far the overall economic gains seems to be comforting in order to not to rock the boat. But regionalism as a whole is more than economy. It involves harmonization and integration in politics, security, economy and the cultural aspects of policy and unity in leading towards a regional community.

It is indeed obvious that bilateralism has helped regionalism to flourish in East Asia in many ways but it remains to be seen if this can be sustained. Regionalism is completely a new game in the 
last two decades. Both China and ASEAN may appear somewhat comfortable in the beginning but things can be difficult in the longer run. Declarations and agreements are easy to be made but difficult to be implemented. It may take perhaps few more decades to foster full swing regionalism in East Asia. While it is easy to acknowledge that Malaysia-China relations have benefitted the two nations and ASEAN in a significant way in upgrading economic relations, regionalism is not all about economic benefits. Security, political will and socio-cultural commonality are different things that need deep thinking. While it is easy to measure economic gains it is difficult to measure the issues and sensitivities in the politico-security and cultural arena.

While globalization and regionalism can increase familiarization, it may also intensify hatred. Some of the reactions coming out of smaller issues of disputes tend to explain that despite years of positive bilateralism and economic exchanges, sensitivities are still high and tensions have not been erased throughout East Asia. The case of China's fishermen in collision with Japanese and Indonesia enforcement officers recently are only tip of the iceberg. Myanmar, Indochina, North Korea, Taiwan, South China Sea and East China Sea are the real issues that will defy the spirit of regionalism. The US for example has been constantly monitoring China's weapon sales outside East Asia, as well as Beijing's major resource and business dealings that are being concluded with authoritarian regimes world around in Africa and Latin America. Having outlined the above, the choices are still limited for smaller countries like Malaysia and others in ASEAN.

It means, regionalism is another strategy that can help mitigate the existing problem with China. ASEAN and the EAS have declared to have an aim for an East Asia Community. The PRC too has an immense opportunity to extend its soft power resources in Asia and to the rest of the world. What Beijing needs is more strategic partners like Malaysia who could work with China with a long term vision. Although Malaysia and ASEAN benefits a lot in this economic dimension, will such relationship last peacefully in the longer run depend very much on how China treats ASEAN and others in the region. The South China Sea issue of late reveals that China could tell ASEAN on how it should behave in dealing with the US on this matter. China has not supported the proposed Code of Conduct in the South China Sea. The case of the Senkaku Island dispute is getting severe since 2012. Japan 
is preparing for potential uneventualities. Several ASEAN countries have yet to fully trust the PRC and struggles in dealing with China bilaterally. ASEAN itself finds China a problem when dealing with Myanmar. China's strong support for Myanmar has made Yangon not to budge on issues of democratization and human rights.

While regionalism is here to stay, the level of regionalism in East Asia is far from what we can imagine. Expansion on trade and economic ties are not sufficient to explain regionalism as full scale liberalization is still very far. There are numerous regulatory barriers. Issues of intellectual property right and copy rights have not been settle under the regional framework. China is not an easy player in this respect. Economic regionalism is still far away in practice except for the promotion of the free trade idea. Although the APT has addressed the issue of currency swap and rescue plan, it has yet to harmonize monetary policy. We can't imagine a single currency in East Asia. This is a long way to go. While some ASEAN members like the way China manage its currency, it may be not so with all the ASEAN members and others in East Asia especially with Japan and South Korea. Economic regionalism in East Asia has been mainly forged based on tariff issues. Issues of non-tariff barriers have a long way to go in forging economic regional integration. Similarly, the issue of creating a single market is not clear. While globalization and regionalism has accelerated the economic linkages, it has yet to bring about the real integration or economic union. Banking and monetary policies are still not harmonized. Currency is still managed and guarded in East Asia. Trade and tariff too have become selective in implementation leaving out many important areas.

\section{CONCLUSION}

The idea of building an East Asian regional community looks very far indeed even though Malaysia and ASEAN have yet to stop exploring and proposing such an initiative. Malaysia's special relations with China have contributed in bringing China closer to Southeast Asia since 1974 and with the end of the Cold War, other Southeast Asian states have followed Malaysia's path and welcomed China into the ASEAN process of wider regionalism for East Asia. The idea of East Asia regionalism has gained significant support albeit some pitfalls. 
While the regionalisation process can be seen as positive, many challenging issues remain unresolved.

The idea of common security, cooperative security, comprehensive and human security needs to be examined once more in understanding regionalism for future and the kind of proposed regional architecture. Politics, economy, security and socio-cultural aspects too are still far away to be fully grasped in East Asia although discussion on the issue seems to be there. National interest and international relations based on realist approach seems to be the dominant feature of intraregional relations in Asia in general. Regionalism too has become a tool and not a solution. East Asian regionalism has yet to address the psychological barriers. Cultural and religious value differences may not appear as a problem but in the longer run differences in societies do matter from a civilizational point of view in embracing liberal and open regionalism. Turkey's absence in the EU is a case in point. Although, the East Asian regional process has been appearing inclusive of late, it started by excluding Western nations like the US, Australia and New Zealand when Mahathir proposed the EAEG. It uses different level and framework of initiatives such as the APT and EAS to overcome the issue of being exclusive and selective. This is not so with the APEC which is far more open. The entry of the US, Russia, India, Australia and New Zealand seems to be addressing the above challenge. However, these inclusions seem to be making regionalism as an ambiguous initiative. There is now the move by ASEAN to make it big by conceptualizing the idea of Regional Comprehensive Economic Partnership (RCEP). Similarly, bilateralism in Malaysia-China relations and ACFTA may not be good indicators of regionalism. Recent incidents have revealed that even ASEAN efforts toward regionalism has yet to achieve much despite numerous meetings, policies and documentations.

The tension in Malaysia-Indonesia relations of late exposes that the number of issues involved just cannot be overcome by regionalism even though there exist ethnic, cultural, value and religious similarities between the Malaysian and Indonesian communities. While a long established ASEAN faces a backlash of this nature, China and East Asian regionalism needs to be examined in proper light. The understanding of what constitutes regionalism must be shared by all with more clarity. Both China-Japan relations and Japan-Korea 
relations are not cordial enough to stimulate regionalism because of security and past historical issues which very often create tension in the region. North Korea and Taiwan can be another important dilemma of regional security. There is also the intensification of balance of power and rivalry caused by the US pivot policy towards the Asia Pacific. Many ASEAN countries which claim to be neutral are not free from openly supporting the US alliance system in Asia.

\section{NOTES}

1 See Heinz Wolfgang Arndt, "Anatomy of Regionalism," Journal of Asian Economics, Vol. 4, No. 2, 1993, pp. 271-282.

2 See Interview with Tan Sri Michael Chen, "It started with a ping pong match," New Straits Times, 31 May 2009.

3 For further details, see John Dalton, "Southeast Asia and China since 1975," Asia Defence Journal, October 1984, pp. 22-27.

4 See Mohamed Jawhar Hassan, "Fresh priorities on well-travelled road," New Straits Times, 28 May 2009.

5 For more details, see Sheldon W Simon, "China and Southeast Asia: Suspicion and Hope," Journal of East Asian Affairs, Vol. 5, No. 1, 1991, pp. 185-202.

6 See K. S. Balakrishnan, "The Globalisation Impact on Malaysia-China Political and Economic Relations," in Emile Kok and Ho Kok Chung (eds.), China and Malaysia in a Globalising World, Kuala Lumpur: Institute of China Studies (ICS), University of Malaya, 2006, pp. 57-70.

7 The author had the privilege of attending numerous speeches by Prime Minister Mahathir in the 1990s while he was working with the Institute of Strategic and International Studies (ISIS) Malaysia, a government-funded think tank that works on policy studies. He also participated in the "Fifth Malaysia-China Bilateral Colloquium: organized jointly by ISIS Malaysia and China Center for International Studies on 20-22 November 1995.

8 See Ministry of Foreign Affairs, People's Republic of China, <www. fmprc.gov.cn>

9 A. Jalil Hamid, "A Successful Tour," New Straits Times, 6 October 2013.

10 "Malaysia seeks to address China trade imbalance," New Straits Times, 19 November 2013.

11 James Hookway, "Asian nations push rival ideas for trade bloc," The Wall Street Journal, 26 October 2009. 